\title{
RUSSIA'S 2021 NATIONAL SECURITY STRATEGY IN THE CONTEXT OF THE STATE'S STRATEGIC CULTURE
}

\section{СТРАТЕГІЯ НАЦІОНАЛЬНОЇ БЕЗПЕКИ РОСІЙСЬКОЇ ФЕДЕРАЦЇ̈ 2021 В КОНТЕКСТІ СТРАТЕГІЧНОЇ КУЛЬТУРИ ДЕРЖАВИ \\ СТРАТЕГИЯ НАЦИОНАЛЬНОЙ БЕЗОПАСНОСТИ РОССИЙСКОЙ ФЕДЕРАЦИИ 2021 В КОНТЕКСТЕ СТРАТЕГИЧЕСКОЙ КУЛЬТУРЫ ГОСУДАРСТВА}

\section{Leszczenko L.}

Prof. UWr, dr hab., University of Wroclaw, Institute of International Studies, e-mail: larysa.leszczenko@uwr.edu.pl

\section{Tarnavska O.}

MA, Ph.D. Student at the Doctoral School at the University of Wroclaw, Institute of International Studies, E-mail: olha.tarnavska@uwr.edu.pl

\section{Лещенко Л.}

Професор Вроцлавського Університету, доктор політичних наук, Вроцлавський Університет, Інститут Міжнародних Студій, e-mail: larysa.leszczenko@uwr.edu.pl

\section{Тарнавська 0.}

Магістр, Аспірантка в Докторській Школі Вроцлавського Університету, Інститут Міжнародних Студій, Е-таil: olha.tarnavska@uwr.edu.pl

\section{Лешенко Л.}

Професор Вроцлавського Університету, доктор політичних наук, Вроцлавський Університет, Інститут Міжнародних Студій, e-mail: larysa.leszczenko@uwr.edu.pl

\section{Тарнавская 0.}

Магистр, Аспирантка в Докторской Школе Вроцлавского Университета, Институт Международных Исследований, E-mail: olha.tarnavska@uwr.edu.pl

Abstract. On 2 July 2021 Russian President Vladimir Putin adopted the National Security Strategy of the Russian Federation. This is one of the most important strategic security document of the state, which presents the key threats and challenges for Russia in changing socio-political realities. The document is also a part of Russian external as well as internal strategic communication. This article seeks to analyze the new NSS in the context of the state's strategic culture and its narratives. Russian strategic culture makes a large impact on the state's identity, which is also affecting Russia's foreign and security policies. New NSS is an informative source of knowledge about the current Russian security culture, which helps to predict the Russian future policy direction.

Keywords: Russia's 2021 National Security Strategy, strategic culture, identity, strategic communication, foreign and security policy.

Анотація. 2 липня 2021 року Президент Росї̈ Володимир Путін підписав Стратегію національної безпеки Російської Федерачії. Це один з найважливіших стратегічних документів держави в галузі безпеки, в якому представлені ключові загрози і виклики для 
Росії в мінливій соиіально-політичній реальності. Документ також $є$ частиною як зовнішніх, так і внутрішніх стратегічних комунікації Росії. У даній статті зроблена спроба проаналізувати нову СНБ в контексті стратегічної культури держави, а також наративів присутніх в стратегії. Російська стратегічна культура має великий вплив на ідентичність держави, щзо також відображається в зовнішній політиці і політиці безпеки Росії. Нова НСБ є досить інформативним джерелом знань про поточну російську стратегічну культуру, що також може допомогти в прогнозуванні майбутньої політики Росії.

Ключові слова: Стратегія нащіональної безпеки Російської Федеращії 2021, стратегічна культура, ідентичність, стратегічні комунікації, зовнішня $i$ безпекова політика.

Аннотация. 2 июля 2021 года Президент России Владимир Путин подписал Стратегию начиональной безопасности Российской Федеращии. Это один из важнейших стратегических документов государства в области безопасности, в котором представлень ключевые угрозы и вызовы для России в меняющейся сочиально-политической реальности. Документ также является частью как внешних, так и внутренних стратегических коммуникачий России. В данной статье предпринята попытка проанализировать новую СНБ в контексте стратегической культурь государства, а также нарративов присутствующих в стратегии. Российская стратегическая культура оказывает огромное влияние на идентичность государства, что также отражается на внешней политике $u$ политике безопастности России. Новая НСБ является информативным источником знаний о текущей российской стратегической культуре, что также может помочь 6 прогнозировании будущей политики России.

Ключевые слова: Стратегия национальной безопасности Российской Федераџии 2021, стратегическая культура, идентичность, стратегические комунникации, внешняя политика и политика безопасности.

Introduction. A National Security Strategy (NSS) is an essential document in a country's security policy, which defines the threats, challenges, priorities, and goals for the coming years. It contains information on how a state positions itself in the international arena, how it interprets the political situation in the world, what threats it considers as existential, and what steps the authorities will take in the future to achieve the goals set out in the strategy. Due to the nature of the document, it is quite general, however, its most important function is to specify the direction of the state's actions in a dynamically changing reality. The NSS is implemented by authorities at different levels of administration within the framework of specific laws and policies. In addition, the NSS plays an important narrative role, as it demonstrates a system of norms, values, and ideological foundations, which create the national identity. The concept of national identity and its impact on foreign and security policy is strongly connected with the strategic culture of a state.

The purpose of the study is to analyze the new National Security Strategy of the Russian Federation, adopted on 2 July 2021 [Указ Президента Российской Федерации от 02.07.2021], and its main narratives in the context of the strategic culture of the Russian state as well as its implication for the future foreign and security policies.

Analysis of recent research and publications. As Aglaya Snetkov pointed out in 2012, "[...] the study of Russian security is predominately a field dominated by positivist ontological analysis" [Snetkov, 2012, p. 522]. The studies were concentrated on the military and economic policies. Since then a lot has changed, mainly due to the Russian hybrid war in Ukraine as well as "the active measures" in the West. The attention is being paid now to ideological issues and Russian identity. Due to the powerful explanatory potential, the knowledge about the strategic culture of the state is crucial in understanding Russia's behavior in global politics. Among the diverse publication 
are works of A. Antczak, R. Kłaczyński, A. Włodkowska-Bagan, N. Eitelhuber, P. Baev, T. German, F. Ermarth, P. Sinovets, E. Rumer and many others. These authors analyze specific features and the long-term changes in Russian strategic culture throughout history.

The main results of the study. The key concept used in this paper is that of strategic culture (SC) which is a significant aspect of statehood. Jack Snyder, who has introduced this concept back in 1977, defines it as "“'the sum total of ideas, conditioned emotional responses, and patterns of habitual behavior that members of a national strategic community have acquired through instruction or imitation." [Snyder 1977] Some other authors broaden further the notion of who is actually the bearer of strategic culture. So, Ken Booth defines SC as: "the concept of strategic culture refers to a nation's traditions, values, attitudes, patterns of behaviour, habits, symbols, achievements and particular ways of adapting to the environment and solving problems with respect to the threat or use of force" [Booth 1990; see also: Lantis and Howlett, 2019].

Strategic culture reflects the character of the state, influences the formulation of strategic goals and directions of state policies. It is an ideological basis and quite often serves as a tool for legitimizing of the policies pursued by the state in international arena. The influence of strategic culture on foreign and security policy is highlighted mainly by the constructivist theory in international relations research. Strategic culture, and the closely related phenomenon of state identity, are influenced by many factors, including history, religion, geopolitical environment, demography, and the form of statehood. As Peter Katzenstein et al wrote: "Cultural or institutional elements of states' global or domestic environments-shape state identity... Variation in state identity, or changes in state identity, affect the national security interests or policies of states. Identities both generate and shape interests." (Jespersin, Wendt, Katzenstein, 1997, p. 15). Scholars try to determine how the identity of states shapes their interests, how a change of national identity brings about a change in state policy and worldwide [Ashizawa, 2008, p. 572]. The SC and the state identity are important concepts that could help to understand current Russian policies and actions. However, when discussing Russia one should keep in mind that depending on the degree of authoritarianism in a country, the role of what Snyder called "national strategic community", as well as its constitution, may fundamentally change.

Snyder also cautioned us about the use of culture as the key explanatory concept: "Cultural explanations tend to be vague in their logic, with causes that are quite distant in time and sequence from their purported consequences. Often, culture is a residual label that is affixed to 'explain' outcomes that cannot be explained in any more concrete way. Thus, culture, including strategic culture, is an explanation to be used only when all else fails." [Snyder 1990, p. 4]

Paying attention to the role of culture and identity is not new. Zbigniew Brzezinski, in his book The Grand Chessboard, analyzing the factors that contributed to the United States' status as the only global superpower after the collapse of the Soviet Union, stresses the importance of American culture and value. Moreover, their appeal to other societies and especially to young people influences the US superpower position [Brzeziński, 1999, p. 24-29].

The impact of globalization on culture in recent decades is undeniable, American cultural patterns still dominate globally, however, due to the rise of China in international politics and its "sharp politics" in public diplomacy [Walker, Ludwig, 2017], the slow weakening of US global leadership, more attention is being paid to the strategic cultures of other countries and their impact on international political order.

As Cezary Dryzd points out, „[...] the term 'strategic culture' is relatively new to the vocabulary of security studies researchers, it has been functioning in science for hundreds of years[...]'[Dryzd, 2017, p. 175]. For many centuries, researchers, state activists, and diplomats have been reflecting on the national character of different state organisms and seeking answers to the question of why states with similar capabilities behave differently. This is an essential knowledge for forecasting and predicting state behavior in different situations. The first analysis in the area of 
strategic culture is usually considered the work History of the Peloponnesian War by Thucydides, in which the author, apart from describing the course of the war between Athens and Sparta, also focuses on the cultural differences between the two nations and their leaderships. Rafał Wiśniewski draws attention that "the concept of strategic culture is a response to the need to take into account subjective factors shaping the foreign and security policy of the state" [Wiśniewski, 2012, p. 163].

Modern research on strategic culture developed during the Cold War and mainly focused on the Soviet area, thanks in part to the 1946 'Long Telegram' from the US Ambassador to Moscow, George Kennan. The term 'strategic culture' was first used in September 1977 by Jack L. Snyder in a report entitled The Soviet Strategic Culture: Implications for Limited Nuclear Operations. The purpose of the report was to try to predict the USSR's behavior in response to limited US nuclear weapons operations [Snyder, 1977, p. iii].

It is worth mentioning that the strategic culture of the Russian empire has been analyzed earlier, for example in the interwar period. In 1938 Włodzimierz Bączkowski, a Polish political scientist, Sovietologist, and publicist, published an article entitled Remarks on the essence of Russian power, in which he quite accurately describes the character of the Russian state, stating that "Russia, whose main state-forming processes took place east of Moscow, is from the point of view of the state (and not only state) culture an Asian state, superficially and externally tinged with Europeanism" [Bączkowski, 1938, p. 3]. The following fragment, which concerns the military sphere, is also worth to be quoted: "...the Russian invasions are the most appropriate manifestation of the power of this country, and the analysis of these wars must necessarily lead us to extract those elements which concentrate the essential content of Moscow's power. If we analyze Russia's invasions, however, we will find that in general Moscow has invaded nations that were either in a state of complete collapse or that offered little resistance" [Bączkowski, 1938, p. 2]. These statements seem to apply equally well to the Soviet Union and Russia under the rule of Vladimir Putin.

Russian strategic culture is an accumulation of historical, social, and political contexts [Ermarth 2009]. Its uniqueness is created by many elements, borrowed from both eastern and western traditions. Robert Kłaczyński, following W. Bączkowski emphasizes that the Russian SC is closer to the eastern culture, especially in terms of its attitude to power [Kłaczyński, 2012, p. 22]. As Anna Antczak argues, "Russia has also a strong history of authoritarian models due to the necessity of control over the huge territory inhabited by different nations, which could be granted only by strong authority."[Antczak, 2018, p. 232]. Contemporary sociological research shows that Russian society believes that only a strong authoritarian power can save Russia from disintegration processes and chaos. As confirmed by the sociological research of the Levada Centre in $2020,3 / 4$ of Russians believe that the state needs a strong and authoritative leader. Notable, that in 1989 only $25 \%$ of respondents thought so [Государственный патернализм 2020]. However, the Chechen wars together with the terrorist attacks at the end of the 1990s changed the Russian public's attitude toward the government.

Among the features of Russian strategic culture, Agata Wlodkowska-Bagan also includes "the syndrome of a besieged fortress and chronic suspicion, the great state and imperial syndrome, as well as the belief in one's own uniqueness and mission with a simultaneous sense of alienation.'[Wlodkowska-Bagan, 2017, p. 42]. The formation of these features has been influenced by history, geography, and wars conducted in different periods of history. The vast territory has always been a source of pride, but also anxiety, regarding an effective defense. After the collapse of the Soviet Union, Russia under President Vladimir Putin hasn't managed to overcome the Soviet heritage and adopt some of the components of the Soviet SC, which causes a lot of problems. Putin's long-standing rule and his entourage have been accompanied by a constant narrative about the external enemy, which is the United States and its NATO allies. Sociological research from May 2021 confirms that around $83 \%$ of Russians believes that Russian states have enemies, with the top five enemy states including the US (66\%), Ukraine (40\%), the UK (28\%), Latvia, and 
Poland (21\%) [Главные “дружественные” и “недружественные” страны, 2021]. It is fair to say that the creation of external enemies has a long tradition in Russian SC and helps the authoritarian regime to survive and to gain public support. Russian policymakers continue to give primacy to military power in international relations, which is why they are developing their armed forces. Moreover, there is a continuation of the Soviet approach to communication policy. Disinformation, propaganda, and the influence on public opinion abroad, as well as surveillance and the fight against opposition within the country, are of strategic importance for Russian policy [Pillars... 2020; Tsetsura, Kruckeberg, 2020].

Indeed, the nation's traditions and values seem to play rather indirect role in strategic decision-making and are to great extent manipulated by authoritarian leaderships is states such as Russia, while official statements or documents are often full of populist promises or outright lies as exemplified well by the Putin's article "Об историческом единстве русских и украинцев“. This ever-present problem was well understood by Snyder, who wrote almost half a century ago: "...doctrinal statements by Soviet military writers and political figures are of limited value..." [Snyder 1977]. In fact, what is really relevant is strategic culture and interpretation of national interests of Vladimir Putin and his rather small immediate circle of advisers, therefore it requires more than reading documents to understand it, but also looking at actions and actual policies [Jesse 2020].

Since Vladimir Putin took power at the beginning of the 21 st century, factors influencing the SC such as history and religion have been completely subordinated to authoritarian rule and have been repeatedly used to legitimize interference in the internal affairs of former Soviet republics, including Ukraine, Georgia, and Belarus. For several decades, Russia has strove to keep the former Soviet republics within its sphere of influence, supporting the ideology of "the Russian world" as a separate cultural and historical space that represents an alternative to Western, liberal values. This is of particular strategic importance for Putin's authoritarian rule, as the democratic development of the former Soviet republics would directly threaten the position of the president and his immediate supporters. Russian history is a source of national pride for its leaders and citizens, and the fact that Russia did not automatically become a world superpower after the collapse of the USSR was and is unacceptable to the Kremlin. Historical events are instrumentalized in the current imperialist policy, which affects relations with other states. A particular increase of Russian "active measures" abroad in this context occurred after the Revolution of Dignity in Ukraine and the occupation of Crimea and Donbas.

The National Security Strategy was adopted on 2 July 2021 and replaces the strategy from 2015. The main document regulating issues related to the NSS is the law "On Strategic Planning in the Russian Federation" from 2014 [Федеральный закон O стратегическом планировании в Российской Федерации, 2014]. The law states that the NSS is the essential document in the sphere of planning the development of the national security system of Russia. The body responsible for preparing the document is the Security Council of the Russian Federation, and the update of the document should take place every six years. Therefore, one should be careful to distinguish general culture of the Russia's population, including attitudes toward related issues, and the strategic culture of its authoritarian leadership, which can only partly be surmised from official documents, but these should be seen in contexts of relevant policies and other deeds. Official documents such as NSS do not necessarily reflects the strategic culture of the Russian nation, but should be seen in the same way as the old Soviet documents, instrument for influencing both internal and external audiences, as is correctly underlined in the text. However, it does provide some useful material to attentive observer for better understanding strategic culture of the ruling elite.

The new NSS identifies nine priority areas of national security: preservation of the Russian people and development of human capital, defense, state, and public security, information security, economic security, scientific and technological development, ecological security and rational use of natural resources, protection of traditional values, culture and historical memory, as well as strategic 
stability and mutually beneficial cooperation. Compared to the previous 2015 NSS, two new priorities have been identified - information security and protection of traditional values, culture, and historical memory.

As Vitaly Yarmolenko points out, "The strategy for the first time consolidates the concept of "sovereign statehood in Russia" (Rus. Суверенная государственность России), which means the state's ability to conduct independent foreign and domestic policy and to effectively resist external pressures." [Ярмоленко, 2021]. The attitude towards the West and the United States has not changed - they remain the most important threat to the Russian state in many key areas. In this NSS framework, this is expressed as the following: "Unfriendly countries are trying to use the socioeconomic problems in the Russian Federation to destroy its internal unity, fuel and radicalize the protest movement, support marginalized groups and divide Russian society." [Указ Президента Российской Федерации от 02.07.2021]. This sentence underlines that any protests in Russia are initiated from abroad and must therefore be suppressed in the interests of security. Allies in the strategy include China, India, the Commonwealth of Independent States, Belarus as part of the Union State, and such international organizations as the Eurasian Economic Union and the Collective Security Treaty Organization. It is important to emphasize that, in the new strategy authors underline the need to develop bilateral cooperation between Russia and the quasi-states of the Republic of Abkhazia and the Republic of South Ossetia.

Another crucial aspect of the strategy is the dangers of the Internet, what is understood as fake news and disinformation about Russia, distorted images of historical facts, appeals to organize public disturbances, and much more. Following in China's footsteps, the Russian authorities recognize the dangers of freedom of expression on the Internet, and for several years they have been taking steps to increase their control over the global network and society respectively. Concerning the activities of the Russian opposition activist Alexei Navalny and his supporters, who managed to organize several major protests in early 2021, there is an activation of efforts to cut Russians off from the global Internet [Domańska, Rogoża, 2021]. Concrete measures were taken in this direction, for example, the so-called "sovereign internet" law, which came into force on 1 November 2019 [Федеральньй закон от 01.05.2019 № 90-Ф3], or the slowing down of Twitter in March 2021 [Rosja rozpoczyna wytaczanie Twittera?, 2021].

Protection of traditional values, culture, and historical memory is one of the top priorities in the national security of the Russian Federation. In the chapter entitled Russia in the modern world: trends and opportunities, it is needed to highlight point $\mathrm{nr} 19$, which states that "the problem of moral leadership and the creation of an attractive ideological stance of the future international order is becoming increasingly relevant" [Указ Президента Российской Федерации от 02.07.2021]. This reflects the tendency to understand Russia as a unique civilization with its values that could constitute an ideological project for the post-soviet states. Russian authorities are aware that the cultural sphere is very important to achieve superpower status in international politics. The document includes the concept of cultural sovereignty, which is the basis of the security of the Russian state and the foundation of Russian society. Cultural sovereignty, according to the authors of the NSS, is threatened by "westernization", and the United States and its allies are explicitly identified as a threat in this area.

Russia's new national security strategy, according to Witold Rodkiewicz and Piotr Żochowski, is, first of all, an element of strategic communication, designed both for its society and for external actors, and reflects "the thinking not only of their authors (who come from the security apparatus) but also for Russia's political leadership (as the authors try to match the content to their expectations)." [Rodkiewicz, Żochowski, 2021]. Analysts from the New Europe Institute write that "it is rather a form of self-promotion and projection of capabilities possessed in the context of engagement on the international arena" [Olech, Pińczak, 2021]. It can also be argued that some elements of Russia's national security strategy are determined by the country's strategic culture, which has evolved over the past few decades since Vladimir Putin has been in power. 
To see the bigger picture of the Russian strategic communication, President Vladimir Putin's article entitled On the Historical Unity of Russians and Ukrainians from July 12, 2021, must be reviewed [Путин, 2021]. It is closely connected with the NSS, which was adopted two weeks earlier. The article does not present a fundamentally new view of the history of Ukraine and the Ukrainian people, as the main narratives have been repeated quite frequently by the Russian President on various occasions. The narratives mainly concern the fact that Ukraine in its present borders is a Soviet creation and that the modern, independent Ukrainian state is the Western "antiRussian" project. The article contains a lot of imperial and Soviet myths and lies about Ukrainian history and identity. Furthermore, due to the order from Russian Defense Minister Sergei Shoigu, the article was added to the military patriotic directorate's curriculum [Статью Путина включили в список, 2021]. It is worth mentioning that the article was translated into Ukrainian and published on official web pages. This means that Russian authorities continue to pursue the imperial politic against Ukrainians. The key aim is to make fundamental changes to the identity of the Russians and Ukrainians, which poses an enormous threat to Ukrainian security and independence. Additionally, the article is an important element of the Russian strategic communication, highlighting the main elements of the SC of the state - the role of history, Orthodox religion, and Russian language as elements building a common space of values, encompassing Ukraine, Belarus, and Russia. Putin once again emphasizes that Russia's aggressive actions towards its neighbors are justified, and this understanding of reality allows the Russian leadership to take all necessary steps to protect the common space and "one nation" from Western-liberal influence. The article amends the NSS in the context of relations with Ukraine, as the authors do not devote any attention to this topic. The NSS only emphasizes the importance of relations with the countries of the Commonwealth of Independent States and the strengthening of brotherly relations between Russians, Ukrainians, and Belarusians.

Conclusions. The new national security strategy of the Russian Federation demonstrates distinct elements of the country's strategic culture. It is primarily concerned with Russia's contemporary position and goals, which are the transforming of the international order and becoming the moral leader in the post-soviet sphere. The "besieged fortress syndrome" is linked to the confrontation with the United States and its allies, which for a long time have been accused of exploiting Russia's weaknesses by interfering in the Russian information environment, or of socalled "exerting control over Ukraine". These actions from the perspective of the Russian leadership, represent an existential threat to Russian interests and security. Importantly, the role of cultural sovereignty is specified, so it becomes an important element of the security strategy. Strengthening the role of the Russian language and the Russian point of view on international affairs abroad will be a priority action for the next few years. The Great Power Syndrome manifests itself in relations with neighboring states, which in the view of the Russian authorities should not be independent actors in international relations. It is worth noting the slight change in the narrative on Ukraine compared to the previous NSS, as the new strategy does not give special importance to the conflict in Donbas. The NSS of the Russian Federation is certainly an element of strategic communication rather than a real list of threats and challenges for the next years.

\section{References}

1. Antczak A., Russia's strategic culture: prisoner of imperial history?, „Athenaeum” 2018, vol. 60 .

2. Ashizawa K., When Identity Matters: State Identity, Regional Institution-Building, and Japanese Foreign Policy, „Europe-Asia Studies” 2008, Vol. 64, No. 3, https://www.jstor.org/stable/25481993?seq=1\#metadata_info_tab_contents

3. Bączkowski W., $O$ istocie sity rosyjskiej, „Wschód-Orient; Kwartalnik poświęcony sprawom Wschodu”, październik-grudzień 1938. 
4. Booth, K. The Concept of Strategic Culture Affirmed. In: Carl G. Jacobsen. Strategic Power: USA/USSR. Springer, 1990, https://link.springer.com/chapter/10.1007/978-1-349-20574-5_8

5. $\quad$ Brzeziński Z., Wielka Szachownica, Warszawa 1999.

6. Domańska M., Rogoża J., Rosja: masowe protesty w obronie Nawalnego, Ośrodek Studiów Wschodnich, 25.01.2021, https://www.osw.waw.pl/pl/publikacje/analizy/2021-01-25/rosjamasowe-protesty-w-obronie-nawalnego

7. Dryzd C., Kultura strategiczna - geneza, definicja i praktyczne zastosowanie, „Roczniki Studenckie Akademii Wojsk Lądowych" 2017, Rocznik 1(I), https://www.wojskopolskie.pl/awl/u/ca/b6/cab64f0a-16d1-4c14-ad44-650dc239a5c7/15_dryzd.pdf

8. Ermarth F.W. Russian Strategic Culture in Flux: Back to the Future? In: Johnson J.L., Kartchner K.M., Larsen J.A. (eds.) Strategic Culture and Weapons of Mass Destruction: Culturally Based Insights into Comparative National Security Policymaking. Palgrave Macmillan, 2009

9. German T., Harnessing protest potential: Russian strategic culture and the colored revolutions, "Contemporary Security Policy" 2020, Vol. 41, No. 4, https://doi.org/10.1080/13523260.2020.1757251

10. Jesse N.G., Learning From Russia's Recent Wars: Why, Where, and When Russia Might Strike Next? Cambria Press, 2020

11. Jepperson L.J., Wendt A., and Katzenstein P.J. Norms, Identity, and Culture in National Security. In: Peter J. Katzenstein (ed.) The Culture of National Security. New York, Columbia University Press, 1997.

12. Kłaczyński R., Kultura strategiczna Federacji Rosyjskiej, „Nowa Polityka Wschodnia” 2012, nr 1 (2).

13. Lantis J.S. Howlett D., Strategic Culture, In: John Baylis, Colin S. Gray, James J. Wirtz (eds.) Strategy in the contemporary world: An introduction to strategic studies. Oxford University Press, 2019

14. Olech K. A., Pińczak L., Najważniejsze tezy Strategii Bezpieczeństwa Narodowego Federacji Rosyjskiej (2021), Insytut Nowej Europy, 05.07.2021, https://ine.org.pl/wpcontent/uploads/2021/07/Najwazniejsze-tezy-Strategii-Bezpieczenstwa-Narodowego-FederacjiRosyjskiej-2021-1.pdf

15. Pillars of Russia's Disinformation and Propaganda Ecosystem. Report, GEC, 2020 https://www.google.com/url?sa=t\&rct=j\&q=\&esrc=s\&source=web\&cd=\&ved=2ahUKEwjy86CJzP LyAhVISfEDHRtSBlgQFnoECAMQAQ\&url=https\%3A\%2F\%2Fwww.state.gov\%2Fwpcontent $\% 2$ Fuploads $\% 2$ F2020\%2F08\%2FPillars-of-Russia\%25E2\%2580\%2599s-Disinformationand-Propaganda-Ecosystem_08-04-20.pdf\&usg=AOvVaw1RAdnah440XcnK-p3mvBgw

16. Rodkiewicz W., Żochowski P., Wróg z Zachodu. Nowa rosyjska strategia bezpieczeństwa, Ośrodek Studiów Wschodnich, 08.07.2021, https://www.osw.waw.pl/pl/publikacje/analizy/202107-08/wrog-z-zachodu-nowa-rosyjska-strategia-bezpieczenstwa

17. Rosja rozpoczyna wytaczanie Twittera?, „Cyberdefence 24”, 10.03.2021, https://www.cyberdefence24.pl/rosja-rozpoczyna-wylaczanie-twittera

18. Snetkov A., When the Internal and External Collide: A Social Constructivist Reading of Russia's Security Policy, "Europe-Asia Studies" 2012, Vol. 64, No. 3, https://www.jstor.org/stable/41495544

19. Snyder L.J., The Soviet Strategic Culture : Implications for Limited Nuclear Operations, RAND Corporation, 1977 http://www.rand.org/content/dam/rand/pubs/reports/2005/R2154.pdf 
20. Snyder L.J., The Concept of Strategic Culture: Caveat Emptor. In: In: Carl G. Jacobsen. Strategic Power: USA/USSR. Springer, 1990, https://link.springer.com/chapter/10.1007/978-1-34920574-5_1

21. Tsetsura K., Kruckeberg D.. Strategic Communications in Russia - Public Relations and Advertising. Routledge, 2020

22. Walker C., Ludwig J., The Meaning of Sharp Power. How Authoritarian States Project Influence, „Foreign Affairs”, 16.11.2017 https://www.foreignaffairs.com/articles/china/2017-1116/meaning-sharp-power

23. Wiśniewski R., Kultura strategiczna, czyli o kulturowych uwarunkowaniach polityki zagranicznej i bezpieczeństwa, „Przegląd Strategiczny” 2012, nr 1.

24. Włodkowska-Bagan A., Kultura strategiczna Rosji, „Sprawy Międzynarodowe” 2017, nr 3, https://www.academia.edu/39505140/Kultura_strategiczna_Rosji

25. Главные “дружественные” и “недружественные” страны, Левада-Центр, 15.06.2021, https://www.levada.ru/2021/06/15/glavnye-druzhestvennye-i-nedruzhestvennye-strany/

26. Государственный патернализм, 25.02.2020, https://www.levada.ru/2020/02/25/gosudarstvennyj-paternalizm/

27. Путин В., Об историческом единстве русских и украинщев, Статья Владимира Путина «Об историческом единстве русских и украинцев» • Президент России (kremlin.ru)

28. Статью Путина включили в список обязательных для изучения военными, „Вести”, 15.07.2021, https://www.vesti.ru/article/2588775

29. Указ Президента Российской Федераџฺи от 02.07.2021 № 400 "О Стратегии национальной безопасности Российской Федерации", Указ Президента Российской Федерации от 02.07.2021 № 400 · Официальное опубликование правовых актов · Официальный интернет-портал правовой информации (pravo.gov.ru)

30. Федеральный закон О стратегическом планировании в Российской Федерации, 25.06.2014, О стратегическом планировании в Российской Федерации (pravo.gov.ru)

31. Федеральный закон от 01.05.2019 № 90-Ф3 "О внесении изменений в Федеральный закон "О связи" и Федеральный закон "Об информации, информационных технологиях и о защитте информащчии", http://publication.pravo.gov.ru/Document/View/0001201905010025

32. Ярмоленко В. В., Щодо нової редакиії Стратегії національної безпеки Російської Федераціï, Національний інститут стратегічних досліджень, https://niss.gov.ua/sites/default/files/2021-07/nova-strategiya-rf.pdf 